\title{
EVALUASI USABILITY PADA SISTEM INFORMASI PERMOHONAN KENDARAAN DINAS (SIMONAS) PT. PLN (PERSERO) UNIT INDUK DISTRIBUSI BALI UP3 BALI UTARA SESUAI ISO 9241-11 DAN EIGHT GOLDEN RULES
}

\author{
Rizki Puji Amini'1), I Made Ardwi Pradnyana2), I Made Agus Wirawan') \\ ${ }^{1}$ Fakultas Teknik dan Kejuruan, Universitas Pendidikan Ganesha \\ ${ }^{2}$ Fakultas Teknik dan Kejuruan, Universitas Pendidikan Ganesha \\ ${ }^{3}$ Fakultas Teknik dan Kejuruan, Universitas Pendidikan Ganesha \\ Email: rizkipujiamini@gmail.com, ardwi.pradnyana@undiksha.ac.id, imade.aguswirawan@undiksha.ac.id
}

\begin{abstract}
Abstrak
SIMONAS atau Sistem Informasi Permohonan Kendaraan Dinas adalah layanan untuk mengelola peminjaman mobil dinas di PT PLN (persero) Unit Induk Distribusi Bali UP3 Bali Utara. SIMONAS perlu dilakukan suatu evaluasi untuk mengetahui tingkat usability yang berguna untuk mengoptimalkan layanan. Metode evaluasi yang digunakan adalah usability testing berbasis ISO 9241-11. Kuisinoner yang digunakan untuk mengukur kepuasan dalam penelitian ini adalah kuesioner SUS. Teknik Performance Measurement dan Restropective Think Aload digunakan untuk mengukur atribut efektivitas dan efisiensi. Subjek dalam penelitian ini adalah pegawai di PT PLN (persero) Unit Induk Distribusi Bali UP3 Bali Utara. Berdasarkan hasil penelitian menunjukkan bahwa: (1) usability testing layanan SIMONAS memiliki tingkat efektifitas dengan rata-rata Completion rate $83,31 \%$ dalam kategori efektif, dan efisiensi diukur menggunakan persamaan time basse efficiency dan overall relative efficiency, serta tingkat kepuasan dalam kategori tingkat penerimaan pengguna masuk dalam kategori marginal, Tingkat grade skala masuk dalam kategori $\mathrm{D}$, dan Adjektif rating masuk dalam kategori good. (2) Rekomendasi perbaikan disesuaikan terhadap saran yang diperoleh dari teknik RTA dan teori Eight Golden Rules yang dilanggar.
\end{abstract}

Kata kunci: Usability, Efisiensi, Efektifitas, Kepuasan, SIMONAS

\begin{abstract}
SIMONAS or the Application Information System to manage official car loans at PT PLN (Persero) UP3 Bali Distribution Main Unit of North Bali. To find out the level of usability and optimize the services required an evaluation. The evaluation method used is usability testing based on ISO 9241-11. The questionnaire used in this study was SUS. Tecnic Performance Measurement and Restropective Think Aload (RTA) are used to measure the attributes of effectiveness and efficiency. The subjects in this study were employees at PT PLN (Persero) Bali Main Distribution Unit UP3 North Bali. Based on the results of indicate that: (1) usability testing SIMONAS services has a level of effectiveness with an average Completion rate of $83,31 \%$ in the effective category, efficiency is measured using the time basse equation efficiency and overall relative efficiency, and the level of satisfaction in the user acceptance category is included in the marginal category, in category $D$, and the objective rating is in the good category. (2) The recommendations generated are adjusted to the suggestions obtained from the RTA technique and the theory of the Eight Golden Rules that were violated.
\end{abstract}

Keywords : Usability, Efficiency, Effectiveness, Satisfaction, SIMONAS 


\section{PENDAHULUAN}

Perkembangan teknologi informasi saat ini berkembang dengan begitu pesatnya. Pengelolaan manajemen instansi saat ini berupaya mengembangkan sistem yang mengandalkan kemajuan teknologi. Sebuah perusahaan akan melakukan perbaikan-perbaikan untuk membuat perusahaan semakin maju dan berkembang. Sistem informasi dapat membantu dalam pengembangan mutu maupun kinerja dari sebuah perusahaan ${ }^{1}$. Usability adalah sejauh mana suatu produk dapat digunakan oleh pengguna tertentu untuk mencapai tujuan tertentu dengan efektivitas, efisiensi dan kepuasan berdasarkan ISO 9241-11. Lama atau tidaknya sebuah sistem informasi bertahan tergantung bagaimana sistem dapat memenuhi kebutuhan penggunanya. Sistem informasi yang baik adalah sistem informasi yang telah dilakukan evaluasi usability untuk mengidentifikasi dan menganalisis permasalahan-permasalahan yang dihadapi pengguna ketika menggunakan sistem informasi.

PT. PLN (Persero) Unit Induk Distribusi Bali UP3 Bali Utara merupakan salah satu cabang dari PT PLN (Persero) Unit Induk Distribusi Bali yang bergerak dalam bidang pelayanan terhadap pelanggan. Salah satunya yaitu perjalanan dinas yang dilakukan para pegawainya. Penggunaan kendaraan dinas merupakan fasilitas pegawai yang diperlukan dalam transportasi kunjungan dinasnya. Berdasarakan hasil wawancara bersama Bapak Eka Tirta Yana selaku SPV ADM MUM, SIMONAS telah digunakan selama dua tahun dan belum dilakukan evaluasi usability terhadap SIMONAS. Keberhasilan SIMONAS tidak hanya dinilai dari bagaimana sistem dapat memproses masukan dan menghasilkan informasi dengan baik, tetapi bagaimana pengguna juga dapat menggunakan dan menerimanya sehingga dapat mencapai tujuan organisasi.

SIMONAS berbasis website ini perlu dievaluasi tingkat kebergunaan (usability) untuk mengetahui seberapa jauh kesesuaian harapan pengguna terhadap sistem. Evaluasi usability penting dilakukan untuk mengevaluasi sebuah produk ${ }^{2}$. Kemudahan antarmuka pengguna juga mempengaruhi apakah sebuah sistem usable atau tidak. Usabilty testing merupakan kegiatan yang dilakukan untuk mendapatkan respon yang komprehensif dari pemakai ${ }^{3}$.

Teori Mandel "Golden Rules of User Interface Design" digunakan sebagai acuan dalam mengukur tingkat penggunaan antarmuka. Golden gules of user interface design terbagi menjadi tiga hal yaitu menempatkan pengguna sebagai kontrol, memudahkan pengguna untuk mengingat, dan konsistensi antarmuka ${ }^{4}$. Evaluasi menggunakan Golden Rules dapat dijadikan sebagai bahan pertimbangan dan referensi pada desain maupun kinerja sebuah sistem.

Berdasarkan hal diatas, maka penulis hendak melakukan penelitian yang berjudul "Evaluasi Usability pada Sistem Informasi Permohonan Kendaraan Dinas (Simonas) PT. PLN (Persero) Unit Induk Distribusi Bali UP3 Bali Utara sesuai ISO 9241-11 dan Eight Golden Rules" yang bertujuan untuk mengevaluasi SIMONAS serta dapat memberikan rekomendasi perbaikan atas sistem tersebut berdasarkan hasil evaluasi usability yang dilakukan.

\section{METODE}

Evaluasi usability pada sistem informasi permohonan kendaraan dinas (SIMONAS) sesuai ISO 9241-11 yang mencakup pada atribut kualitas efektivitas, efisiensi, dan kepuasan. Metode evaluasi usability testing yang digunakan yaitu menggunakan teknik Performance Measurement, teknik Restropective Think Aloud (RTA). Kuesioner SUS (System Usability Scale) dikombinasikan dengan teknik RTA dan Performance Measurement untuk mengeksplorasi pengalaman pengguna dalam berinteraksi dengan sistem. Kuesioner SUS digunakan karena dalam melakukan pengujian lebih menekankan perspektif pengguna akhir sehingga hasil evaluasi akan lebih sesuai dengan keadaan nyata serta kuesioner SUS lebih menekankan perspektif pengguna akhir sehingga hasil evaluasi akan lebih sesuai dengan keadaan nyata ${ }^{5}$. SUS telah dilakukan dalam usability testing terhadap aplikasi kepegawaian di kota Bandung yang menghasilkan sebuah indeks kelayakan sebuah sistem informasi untuk tetap digunakan atau tidak ${ }^{6}$. Hingga saat ini SUS banyak digunakan untuk mengukur usability dan menunjukkan beberapa keunggulan yaitu dapat digunakan dengan mudah karena hasil berupa skor 0-100, tidak membutuhkan perhitungan yang rumit, tersedia secara gratis dan terbukti valid dan reliable walau dengan ukuran sampel yang kecil

Metode usability testing dengan teknik Restropective Think Aload (RTA dilakukan untuk mendalami pikiran atau perasaan pengguna setelah menggunakan sistem, memberikan kesempatan pada responden untuk menceritakan pengalaman selama menggunakan sistem dan Teknik Performace dilakukan untuk menguji efektivitas yang dapat diukur dari ketepatan atau keakuratan dalam 
menyelesaikan task skenario ketika melakukan usability testing ${ }^{8}$. Hal ini bertujuan untuk mengidentifikasi masalah kegunaan, mengumpulkan data kualitatif dan kuantitatif, serta menentukan kepuasaan pengguna terhadap produk. Keunggulan dalam penelitian ini adalah melibatkan responden untuk berinteraksi langsung terhadap sistem sehingga dalam mengeksplorasi pengalaman pengguna dapat dipadukan dengan kuesioner SUS.

Prosedur penelitian dalam penelitian ini diawali dengan menyusun task skenario yang akan dijadikan acuan responden dalam menyelesaikan tugas. Skenario menggambarkan kisah dan konteks dibalik mengapa pengguna atau grup pengguna tertentu datang pada suatu situs ${ }^{9}$. Saat mengdentifikasi skenario untuk pengujian usability, jumlah task yang seharusnya dilakukan dibatasi sepuluh hingga dua belas task karena keterbatasan waktu. Sepuluh hingga dua belas pertanyaan dianggap ideal untuk menghindari kejenuhan dan kelelahan partisipan, pertanyaan telah dirancang dengan baik sebelumnya guna memberikan pertanyaan yang akan memberikan informasi yang dibutuhkan ${ }^{10}$. Task skenario disusun berdasarkan pekerjaan-pekerjaan yang dapat dilakukan dalam sistem. Setiap responden menyelesaikan task skenario yang sama. Dalam peneletian ini terdapat enam buah task skenario yang akan dikerjakan oleh responden. Penyusunan instrumen dalam usability testing terhadap SIMONAS yaitu dengan menggunakan kuesioner SUS yang mengacu pada Standart Usability Questionare. Task skenario dan kuesioner SUS yang telah disiapkan selanjutnya akan dikerjakan oleh setiap responden. Sampel untuk melakukan usablity testing pada SIMONAS adalah sebanyak sepuluh orang untuk mendapatkan hasil akhir yang baik. Kriteria responden dalam penelitian ini adalah pegawai PT. PLN (persero) Unit Induk Distribusi Bali UP3 Bali Utara diseluruh bidang.

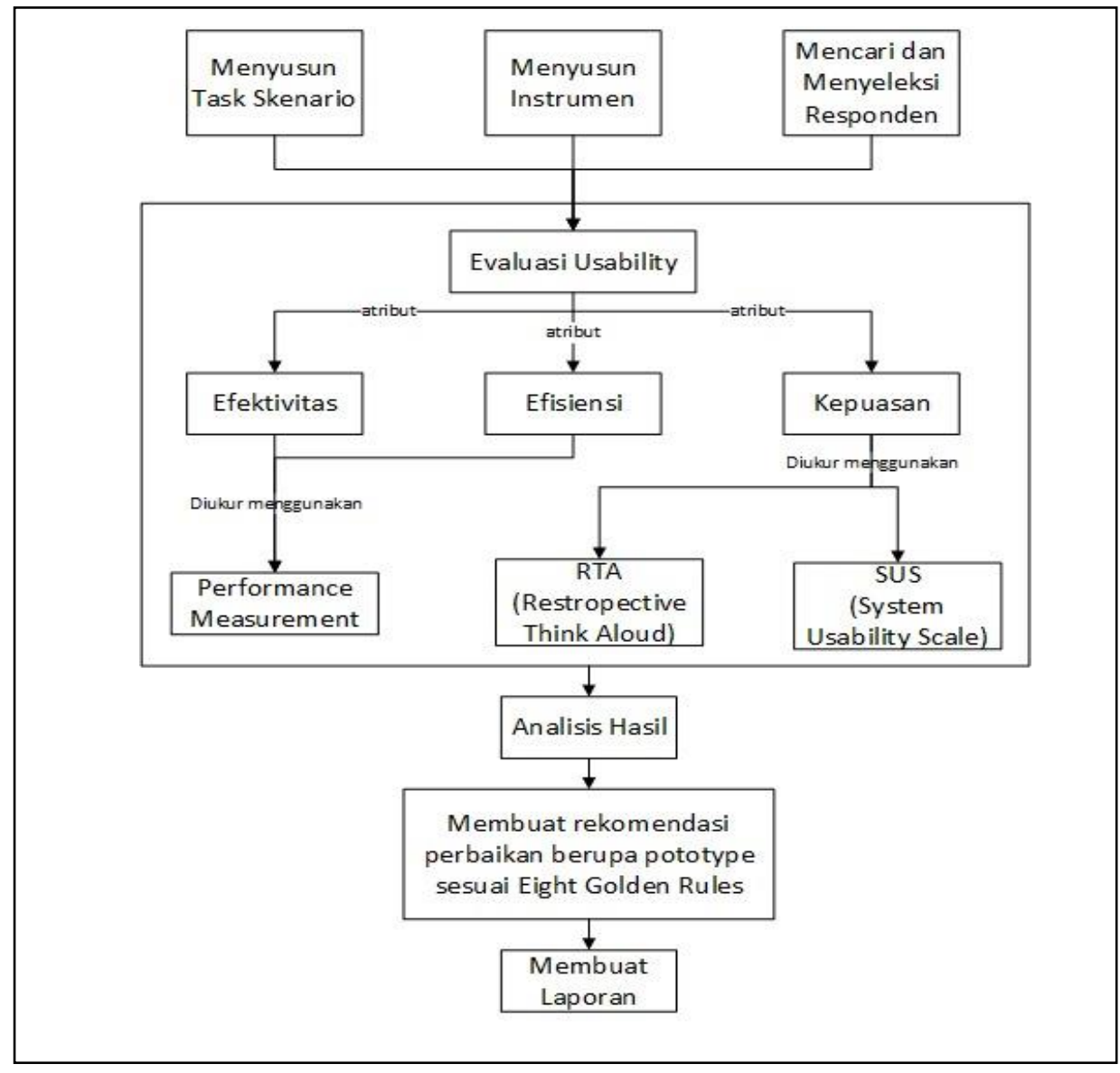

Gambar 1. Prosedur Penelitian 


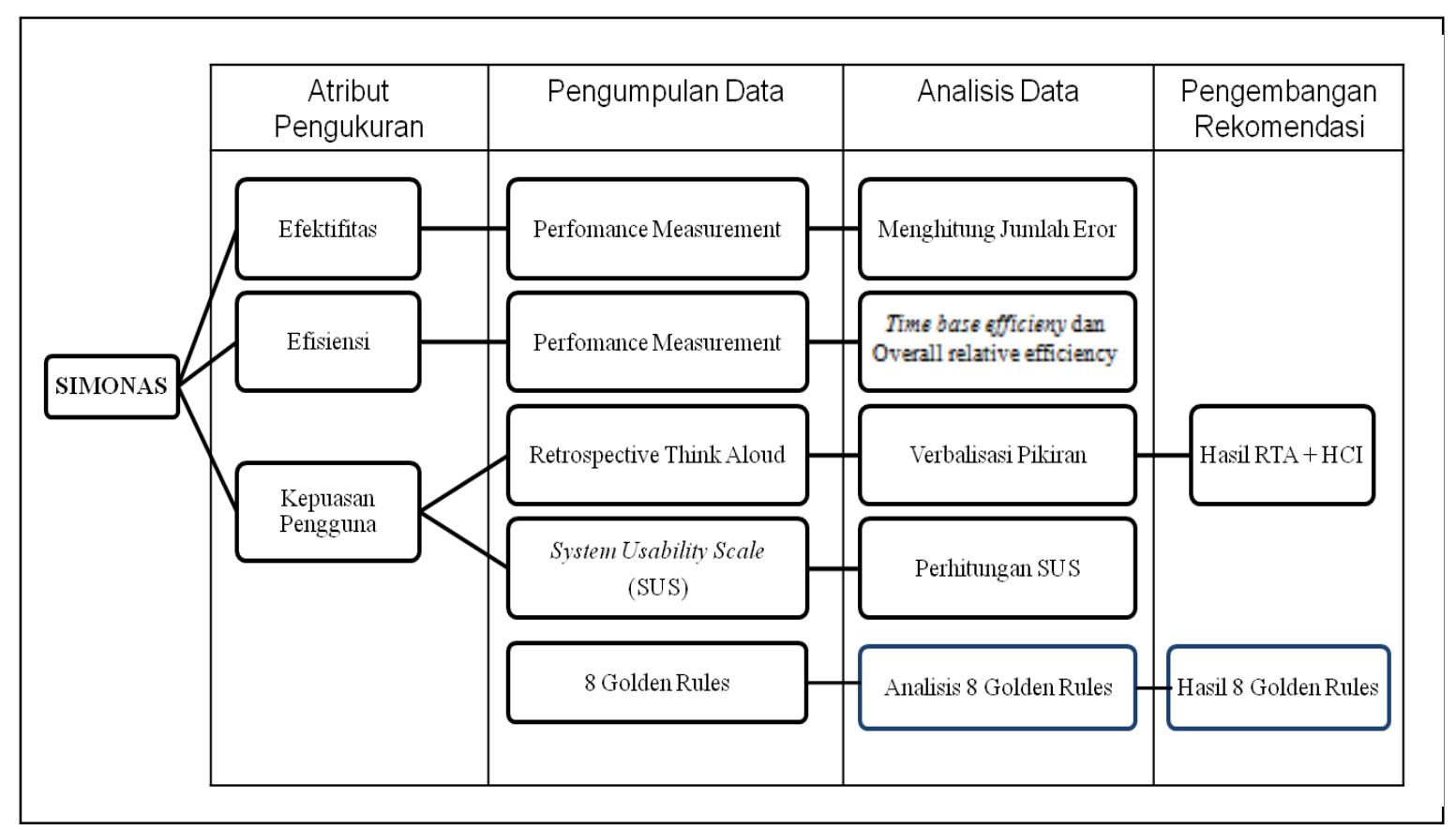

Gambar 2. Teknik Pengumpulan Data

Pada Gambar 2 menjabarkan secara garis besar teknik yang digunakan dalam penelitian. Evaluasi Usability SIMONAS selanjutnya dilakukan dengan mengevaluasi tiga atribut sesuai ISO 9241-11 yaitu atribut Efektivitas dan Efisiensi diukur menggunakan Performance Measurement, dan atribut kepuasan diukur dengan menggunakan Restropective Think Aload dan kuesioner SUS. Hasil dari Evaluasi Usability SIMONAS tersebut kemudian dianalisis agar mendapatkan hasil dari ketiga atribut yang diuji sehingga berdasarkan acuan hasil yang diperoleh dibuatlah wireframe rekomendasikan perbaikan sesuai delapan aturan emas oleh Ben Shneiderman.

\section{HASIL DAN PEMBAHASAN}

\section{A. EFEKTIFITAS}

Analisis efektivitas diukur dengan menghitung jumlah tugas yang berhasil diselesaikan oleh responden. Hasil tersebut kemudian diolah dengan menggunakan rumus Completion rate. Banyaknya tugas yang diselesaikan dan berhasil dibagi banyaknya total tugas yang diberikan yang hasilnya kemudian dikalikan dengan $100 \%$.

\begin{tabular}{ccc}
$\begin{array}{c}\text { Kode } \\
\text { Rabel 1 }\end{array}$ & $\begin{array}{c}\text { Efektifitas Responden } \\
\text { Task } \\
\text { Rerhasil } \\
\text { diselesaikan }\end{array}$ & $\begin{array}{c}\text { Completion } \\
\text { rate }\end{array}$ \\
\hline 01 & 6 & $100 \%$ \\
02 & 6 & $100 \%$ \\
03 & 6 & $100 \%$ \\
04 & 5 & $83,3 \%$ \\
05 & 5 & $83,3 \%$ \\
06 & 6 & $100 \%$ \\
07 & 5 & $83,3 \%$ \\
08 & 6 & $100 \%$ \\
09 & 4 & $66,6 \%$ \\
10 & 4 & $66,6 \%$ \\
\hline Rata-rata efektifitas & $88,31 \%$ \\
\hline
\end{tabular}

Berdasarkan rata-rata yang diperoleh dari hasil efektifitas tiap responden menunjukkan keakuratan dan kelengkapan responden untuk mencapai tujuan dalam menggunakan SIMONAS adalah $88,31 \%$. 
Rata-rata penyelesaian tugas minimum pada pengujian usability adalah $78 \%$, namun bila hasil dibawah 49\% menempatkan pada kuartil bawah (Sauro, 2011), sehingga hasil rata-rata keefektifitasan SIMONAS yang menghasilkan $83,31 \%$ tersebut termasuk dalam kategori efektif.

B. EFISIENSI

Data yang digunakan untuk mengukur komponen ini adalah waktu yang dibutuhkan responden mulai dari awal melakukan tugas sampai tugas diselesaikan atau gagal diselesaikan pada setiap tugasnya. Efisiensi dihitung dengan menggunakan rumus time based efficiency dan overall relative efficiency. Berikut pada tabel 2 hasil perhitungan time based efficiency dengan satuan goals/sec dan overall relative effciency.

Tabel 2.

Hasil perhitungan time based efficiency dan overall relative effciency.

\begin{tabular}{ccc} 
Task & $\begin{array}{c}\text { Hasil Time Based } \\
\text { Effciency }\end{array}$ & $\begin{array}{c}\text { Hasil Overall } \\
\text { Relative Efficiency }\end{array}$ \\
\hline 1 & 0,06 goals $/ \mathrm{sec}$ & $100 \%$ \\
2 & 0,04969 goals $/ \mathrm{sec}$ & $96,5 \%$ \\
3 & 0,11817 goals $/ \mathrm{sec}$ & $86,9 \%$ \\
4 & 0,00855 goals $/ \mathrm{sec}$ & $100 \%$ \\
5 & 0,02437 goals $/ \mathrm{sec}$ & $88,3 \%$ \\
6 & 0,04556 goals $/ \mathrm{sec}$ & $86,7 \%$ \\
\hline
\end{tabular}

Time based efficiency merepresentasikan tingkat kecepatan pengguna dalam mencari informasi yang dibutuhkan pada sebuah aplikasi. Perhitungan overall relative effisiency untuk mengukur keseluruhan menggunakan rasio waktu yang dibutuhkan pengguna yang berhasil menyelesaikan tugas dengan total waktu yang diambil dari total waktu responden.

\section{KEPUASAN PENGGUNA}

Data yang diperlukan untuk mengukur kepuasan pengguna adalah dengan kuesioner SUS yang telah diisi oleh 10 responden pengguna SIMONAS. Hal yang terlebih dahulu dilakukan adalah menghitung nilai skor untuk masing-masing pernyataan dari tiap responden. Penentuan pertama dilihat dari sisi tingkat penerimaan pengguna, grade skala dan adjektif rating yang terdiri dari tingkat penerimaan pengguna terdapat tiga kategori yaitu not acceptable, marginal dan acceptable. Penentuan Acceptability, grade scale, adjective rating digunakan untuk melihat sejauh mana perspective pengguna terhadap SIMONAS. Untuk menentukan Acceptability, grade scale, adjective rating maka dilakukan perbandingan hasil penilaian rata-rata responden sebesar 64,09 (enam puluh empat koma nol sembilan) dengan ketentuan penilaian seperti Gambar 3. Hasil penilaian yang diberikan responden maka hasil penilaian terhadap SIMONAS adalah a) Tingkat penerimaan pengguna masuk dalam kategori marginal, b) Tingkat grade skala masuk dalam kategori $D$, dan $c$ ) Adjektif rating masuk dalam kategori good.

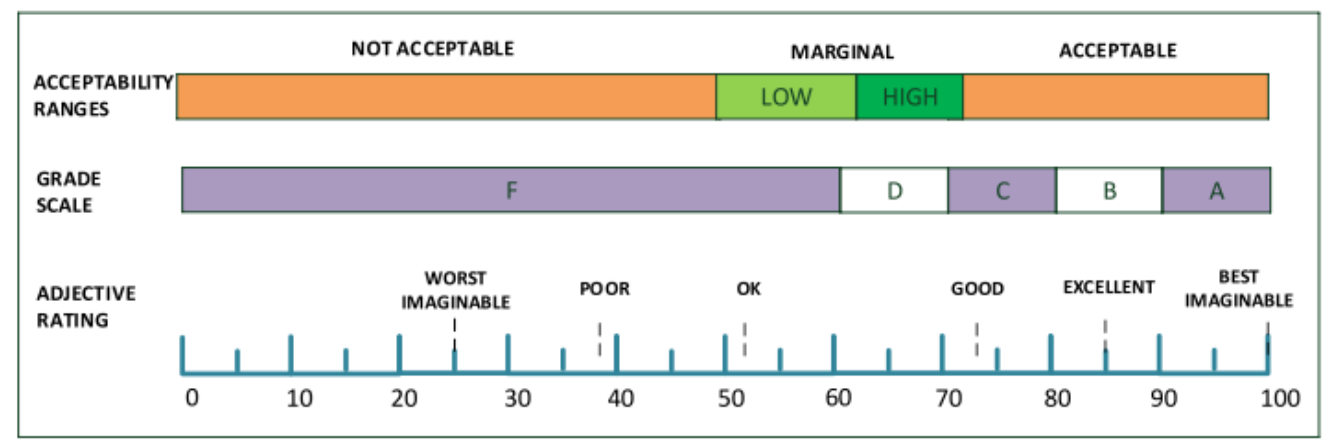

Gambar 3. Kategori nilai SUS (Pudjoatmodjo \& Wijaya, 2016)

Berdasarkan hasil penilaian tersebut maka SIMONAS belum dapat digunakan dengan mudah oleh pengguna akhir. Selain hasil kepuasan yang diperoleh menggunakan kuesioner SUS, diperoleh pula hasil verbalisasi pemikiran responden. Verbalisasi tersebut meliputi kesan pesan ataupun kesulitan 
yang diutarakan responden saat sesi pengujian berakhir. Proses penggalian informasi dipengaruhi oleh keadaan lingkungan dan usaha peneliti dalam mengarahkan responden. Hasil dari verbalisasi yang dimaksud dapat diamati pada hasil Restropective Think Aload.

\section{REKOMENDASI PERBAIKAN}

Rekomendasi perbaikan berupa rancangan/ wireframe menggunakan aplikasi mock up, yang mengacu pada teori perancangan. Teori tersebut yaitu eight golden rules oleh Benn Shneiderman.

Berikut pembahasan delapan aturan emas pada layanan SIMONAS.

a) Berusaha untuk konsisten (Strive for consistency). Konsistensi SIMONAS dilihat dari ukuran font , gambar, logo, maupun posisi sudah konsisten sehingga pengguna tidak mengalami kesulitan dalam beradaptasi dengan desain tampilan.

b) Melayani kebutuhan berbagai pengguna (Cater to universal usability). Melayani kebutuhan pengguna dari berbagai kalangan misalnya pemula/mahir dengan menyediakan fitur tertentu yang mendukung pengguna mahir untuk mengurangi jumlah interaksi dibandingkan pengguna pemula. Misalnya memberikan shortcut pada menu yang sering diakses/digunakan. Pada layanan ini tidak mendukung fitur khusus tersebut.

c) Memberikan umpan balik yang informatif ( Offer informative feedback). Menawarkan umpan balik yang informative dalam tindakan tertentu misalnya melakukan kesalahan dalam mengerjakan suatu taks dan memberikan solusi terhadap masalah yang terjadi. Pada layanan SIMONAS bagian ini terlihat ketika melakukan proses penginputan data tujuan keberangkatan dan pengisian data catatan untuk admin apabila tidak diisi maka terdapat pemberitahuan untuk melengkapinya. Bagian lain terkait menu yang belum berfungsi belum memberikan informasi terkait keterangan bila menu yang dipilih belum tersedia/ tidak dapat digunakan.

d) Merancang dialog yang memberikan penutupan akhir (Design dialogs to yield closure). SIMONAS telah memberikan kejelasan kepada pengguna ketika proses pengajuan permohonan telah dilakukan. Adanya tampilan informasi mengenai data yang telah diinput berhasil disimpan membuat pengguna merasa bahwa proses yang dialui benar-benar telah selesai dan tidak adalagi langkah lainnya yang perlu dikerjakan.

e) Mencegah kesalahan (Prevent errors). Mencegah kesalahan yang dilakukan pengguna dengan umpan balik yang informative. Masih terdapat bagian yang belum mencegah kesalahan ketika memilih kendaran yang akan digunakan pegawai. Pada tahap pemilihan mobil belum adanya informasi atau keterangan ketika mobil yang dipilih sudah dipesan oleh pegawai lain ketika mengakses SIMONAS dalam waktu yang bersamaan.

f) Memungkinkan pembalikan aksi yang mudah (Permit easy reversak of actions). Fitur edit/back untuk mengoreksi kesalahan yang dilakukan. Saat pengguna SIMONAS melakukan kesalahan dengan memilih menu lain secara tidak sengaja, namun masih dalam tahap penginputan data. Pengguna tidak perlu menginput ulang data yang telah diisi karena pada SIMONAS telah ada fitur back untuk kembali keproses sebelumnya atau untuk membetalkan perintah terakhir.

g) Mendukung pusat kendali internal (Support internal locus of control). Mendukung fitur bantuan. Layanan ini masih belum mendukung fitur bantuan yang terdapat pada menu, pengguna akan menyesuaikan berdasarkan aturan yang berlaku.

h) Mengurangi beban jangka pendek (Reduce short-term memory load). Ketika pengguna berada pada halaman history permohonan, hal pertama yang dirasakan pengguna adalah kebingungan karena tampilan history permohonan menampilkan seluruh permohonan pegawai. Kata kunci nama pemohon digunakan dalam mencari history tidak dapat digunakan, terlebih lagi history permohonan ditampilkan secara acak tidak terurut dari permohonan terbaru hingga permohonan terlama. Hal inilah yang membuat pegawai berfikir keras untuk mencari history yang telah dibuatnya.

Berdasarkan eight golden rules terhadap SIMONAS diatas, adapun dasar perbaikan yang dirumuskan adalah sebagai berikut:

\section{Menu Dashboard}

Gambar 4 merupakan gambar awal sebelum perbaikan dilakukan. Aturan yang dilanggar pada teori 8 golden rules yakni feedback informative. Pelanggaran aturan tersebut dapat diamati pada menu utama yang tidak menampilkan informasi laman yang sedang diakses (ditunjukkan pada nomor 1). Pada history permohonan yang tampil pada dashboard (ditunjukkan pada nomor 2) tidak dapat digunakan untuk melihat detail history permohonan, padahal ketika cursor mengarah pada bagian tersebut telah terjadi perubahan warna sebagai umpan balik pengguna bahwa bagian itu bisa diakses namun nyatanya tidak dapat digunakan. Pada kotak nomor tiga merupakan informasi hak cipta yang mencantumkan dua nama, cukuplah mencantumkan nama instansi sebagai pengatur pemegang hak 
tersebut untuk membatasi penggandaan tidak sah atas suatu ciptaan. Bagian lain yang dilanggar yaitu fitur pintasan/shortcut terkait menu yang sering diakses. Penggunaan menu pengajuan permohonan untuk melalukan join keberangkatan menyebabkan pengunjung mengalami kesulitan dalam menemukan menu yang dimaksud.

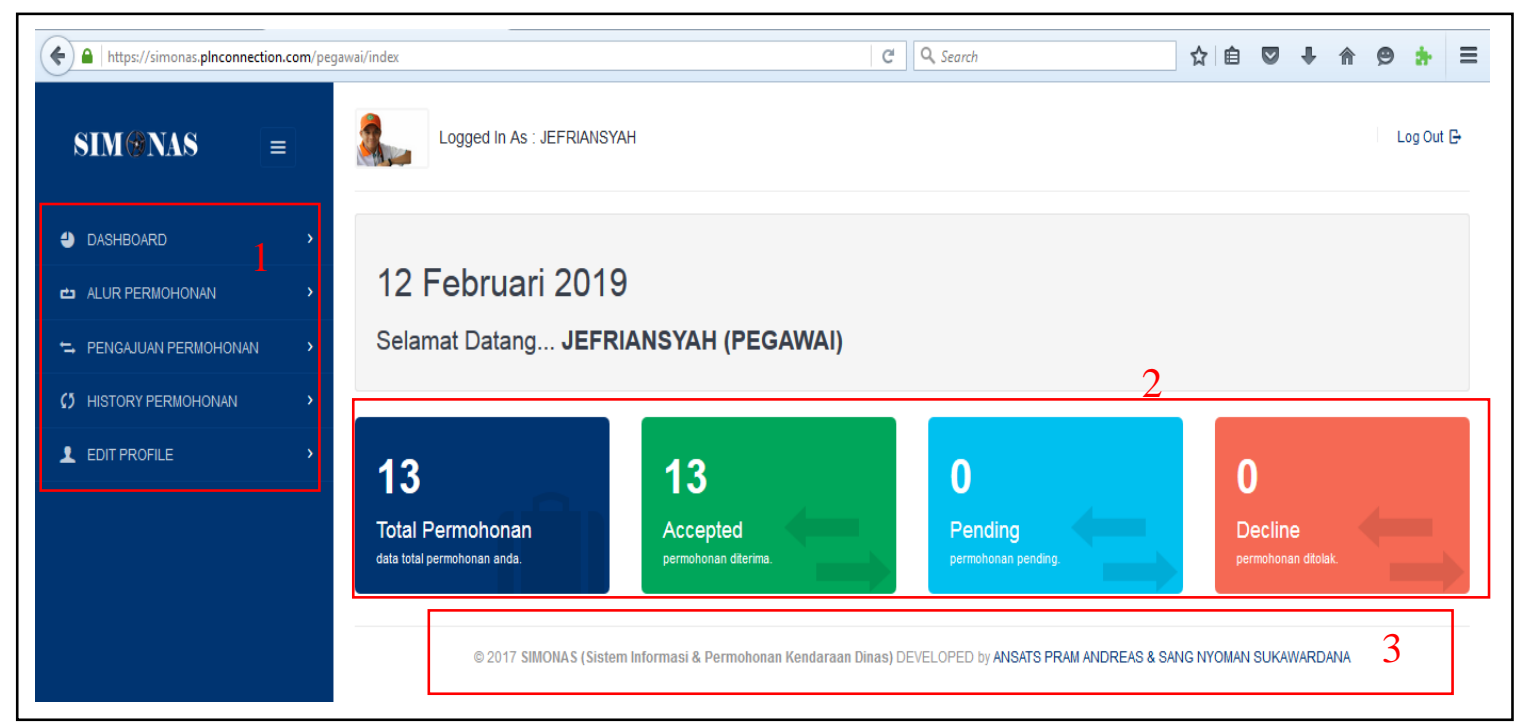

Gambar 4. Tampilan Dashboard SIMONAS sebelumnya

Tata letak pada tampilan tampilan menu utama tidak dikelompokkan secara teratur, ada bagian yang tampil pada bagian menu utama yang sebaiknya ditampilkan pada submenu dan ada bagian yang harus ditampilkan pada submenu namun tidak ditampilkan sehingga membuat pengunjung berpikir keras untuk menemukannya. Seperti yang dialami oleh responden 08 yang bingung melakuan join karena tidak tahu dimana letak halaman untuk melakukannya.

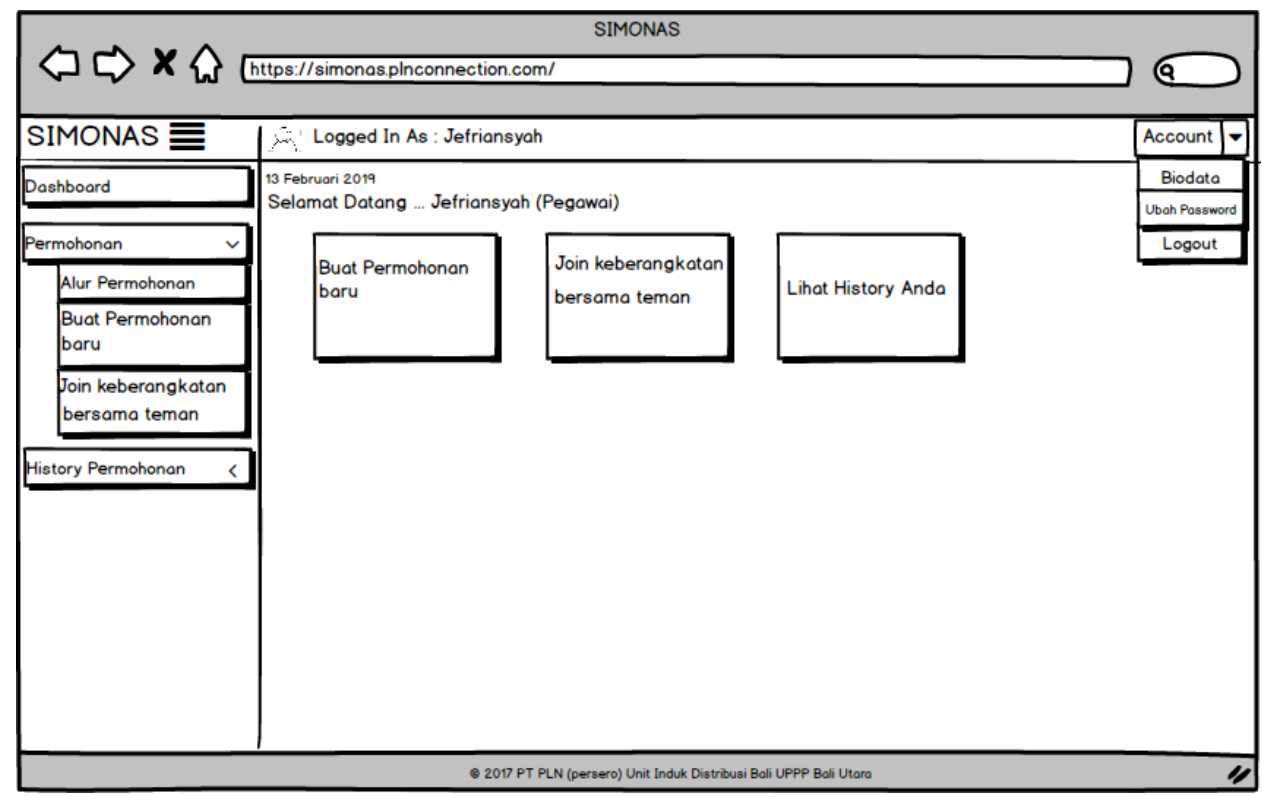

Gambar 5. Saran perbaikan tampilan Dashboard

Saran tampilan pada halaman dashboard pada gambar 5 adalah adanya pengerucutan menu utama. Menu yang tidak tampil pada menu utama tersebut akan muncul pada submenu pada kelompok menu yang sesuai. Menu edit profile tidak lagi terletak pada barisan menu utama melainkan tampil pada menu account yang terletak pada pojok kanan atas. Penambahan shortcut pengajuan permohonan baru, join keberangkatan bersama teman dan lihat history Anda adalah untuk memudahan pegawai dalam mengakses menu yang sering digunakan. Pada menu 
dashoard dibuat lebih gelap dari menu lainnya sebagai tanda kepada pengguna bahwa halaman tersebutlah yang kini sedang terbuka.

\section{Menu Permohonan}

Pada saran gambar 6 terlihat bahwa ada tiga submenu yang ada ada menu utama Permohonan. Hal ini berfungsi untuk memudahkan pengguna untuk melakukan pilihan yang diinginkan. Warna lebih gelap pada submenu alur permohonan menunjukkan halaman yang sedang dibuka.

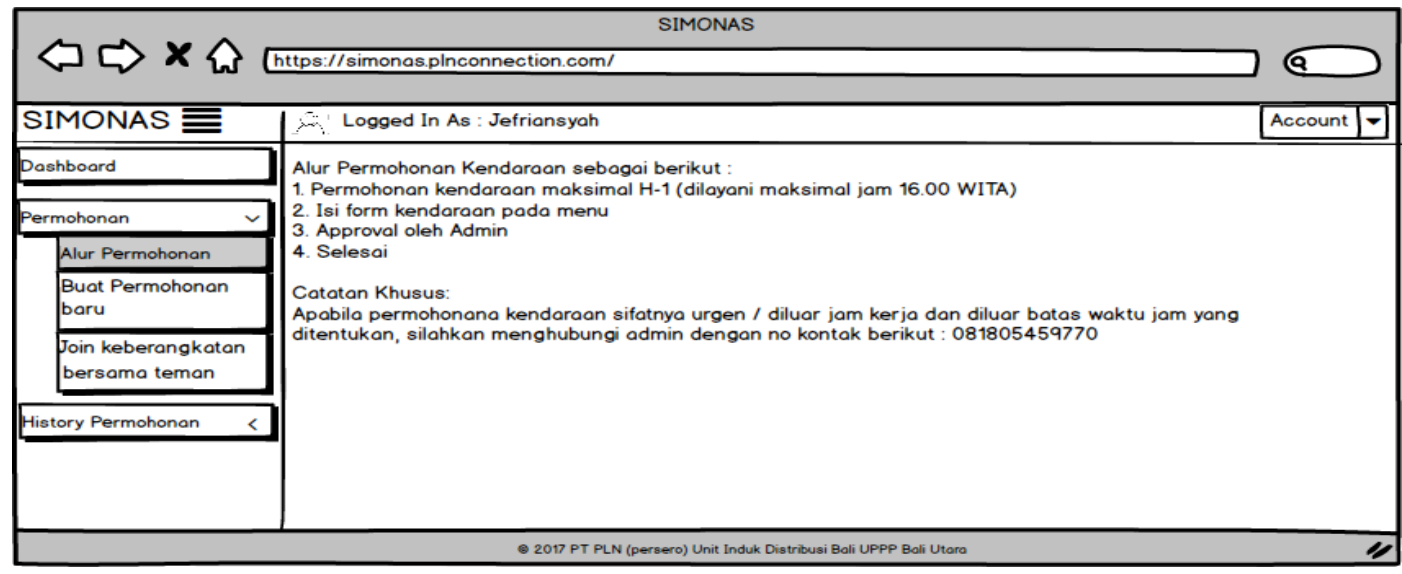

\section{Gambar 6}

Saran perbaikan tampilan Pengajuan Permohonan

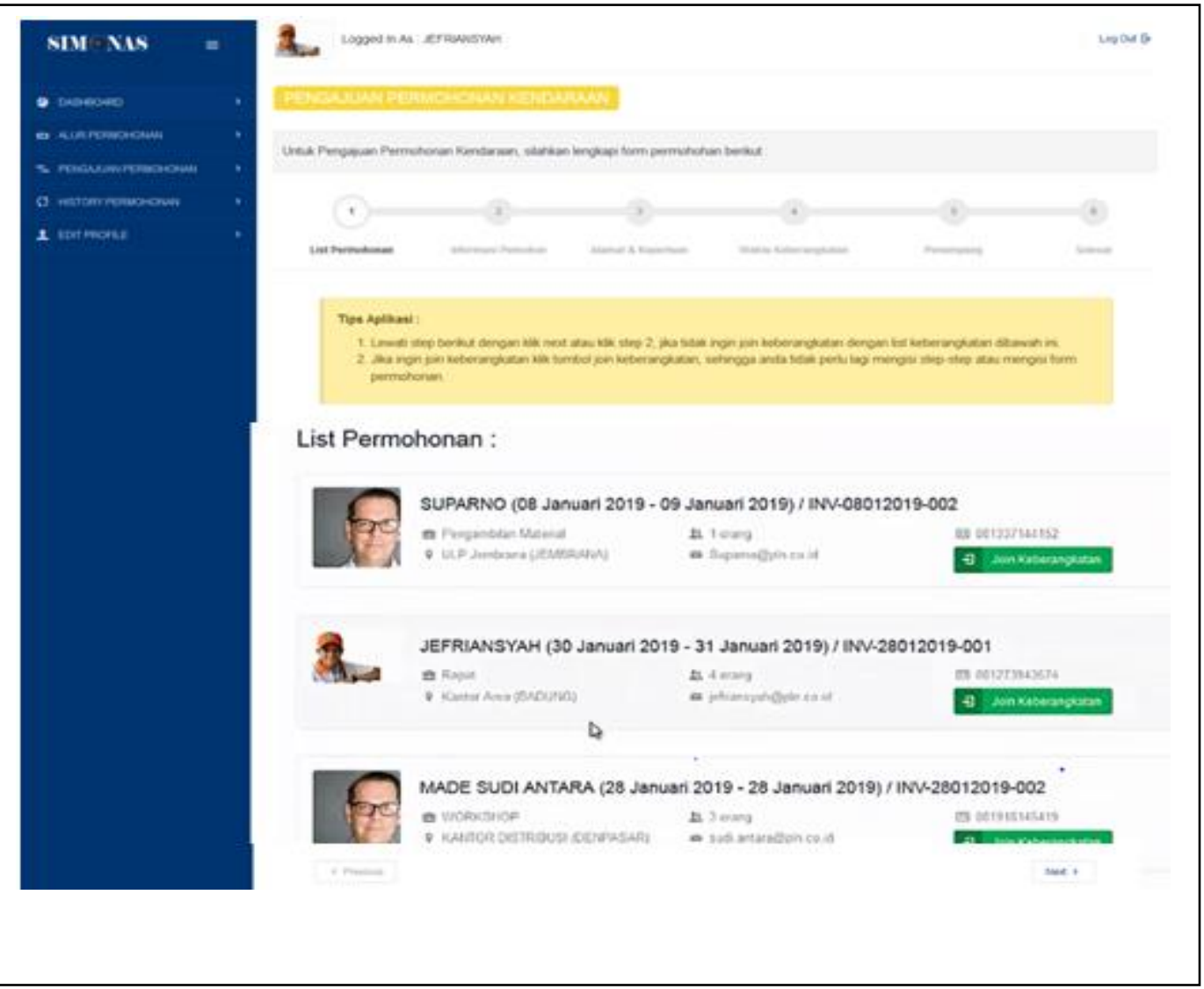

Gambar 7. Tampilan Pengajuan Permohonan sebelumnya

Pada gambar 7 merupakan tampilan halaman pengajuan permohonan sebelum dilakukan perubahan. Halaman tampilan tersebut dijadikan satu antara list permohonan yang telah dibuat oleh pegawai dan pengajuan permohonan kendaraan baru. Sehingga ketika 
pegawai ingin melakukan join keberangkatan akan bingung ketika melihat menu utama yang tidak memberikan keterangan join keberangkatan. Hal ini seperti yang telah dilakukan responden 8 kebingungan untuk melakukan join keberangkatan.

\section{SIMPULAN DAN SARAN}

Adapun kesimpulan penelitian ini yaitu, (1) Pada atribut efektivitas diperoleh hasil yaitu SIMONAS dapat membantu menyelesaikan tugas dan mencapai tujuan. Berdasarkan hasil akhir nilai rerata Completion rate yang dihasilkan yaitu $90 \%$ maka dapat disimpulkan SIMONAS termasuk dalam ketegori efektif. (2) Efisiensi. Variabel yang berhubungan dengan perbandingan kecepatan waktu pegerjaan tugas oleh responden. Adapun analisis yang digunakan untuk menghitung keefisiensinan SIMONAS menggunakan rumus time bassed efficiency. Berdasarkan hasil perhitungan time based efficiency, tingkat kecepatan pengguna dalam mencari informasi yang dibutuhkan dalam SIMONAS sebesar 0,060001 untuk tugas $1,0,062118$ untuk tugas $2,0,147711$ untuk tugas $3,0,008552$ untuk tugas 4, 0,024367 untuk tugas 5, dan 0,045556 untuk tugas 6 tiap detiknya berdasarkan dari keseluruhan waktu yang dibutuhkan oleh keseluruhan responden untuk menyelesaikan tugas. (3) Perolehan hasil kepuasan menggunakan kuesioner SUS diperoleh hasil rata-rata sebesar 64,09. Sesuai dengan hasil penilaian tersebut maka SIMONAS belum dapat digunakan dengan mudah oleh pengguna akhir. Menurut Penentuan Acceptability, grade scale, adjective rating maka tingkat penerimaan pengguna masuk dalam kategori marginal, tingkat grade skala masuk dalam kategori $\mathrm{D}$, dan Adjektif rating masuk dalam kategori good. (4) Rekomendasi perbaikan diimplementasikan dalam bentuk rancangan diperoleh berdasarkan hasil RTA. Berdasarkan saran masukan yang dikumpulkan dari teknik tersebut, dan dikombinasikan dengan teori perancangan sesuai aturan eight golden rules yang masih dilanggar diantaranya (a) Tidak memberikan umpan balik yang informatif pada setiap halaman SIMONAS. (b) Kurangnya mengurangi beban ingatan jangka pendek akibat beberapa laman yang mengundang pertanyaan saat diakses. (c) Adanya simbol-simbol yang tampil namun tidak dapat digunakan. (d) Menu utama yang masih kurang jelas

Saran peneliti berdasarkan beberapa hal yang dapat dijadikan sebagai bahan pertimbangan untuk ditindak lanjuti yaitu penelitian ini mengadopsi ISO 9241-11 dan dapat dimplementasikan menggunakan variable lain untuk mengetahui hasil dari varibel yang belum diujikan agar atribut pengujian tidak hanya mengevaluasi efektifitas, efisiensi dan kepuasan pengguna saja. Penelitian ini tidak mengelompokkan responden mahir dan responden pemula sehingga dalam penentuan atribut efisiensi dalam penelitian ini dengan cara membandingkan waktu yang dihabiskan tiap responden. Adanya pengelompokkan responden mahir dan pemula dapat membantu dalam proses menentukan keefisienan dengan cara membandingkan waktu penyelesaian tugas responden. Hasil rekomendasi perbaikan berupa wireframe belum diuji ahlikan sesuai aturan eight golden rules, sehingga penelitian selanjutnya dapat melakukan uji ahli mengenai hal tersebut.

\section{DAFTAR PUSTAKA}

[1] Subchan, \& Kusuma Ardi, B. (2014). No. 36 / Th. XXI / April 2014 Jurnal Ekonomi Manajemen dan Akuntansi, (36), 1-14.

[2] Rubin, J., \& Chisnell, D. (2008). Handbook of usability testing [electronic resource]: How to plan, design, and conduct effective tests (2nd ed.). Indianapolis, IN: Wiley Pub. https://doi.org/10.1007/s13398-014-0173-7.2

[3] Utama, S. (2011). Perbaikan User Interface Halaman Internet Banking dengan Metode Usability Testing. Universitas Indonesia.

[4] Yasin, A., Mz, Y., \& Mandel, T. (2016). EVALUASI WEB UJB MENGGUNAKAN G OLDEN RULES OF USER INTERFACE DESIGN THEO MANDEL, 6-7.

[5] Ependi, U., Panjaitan, F., \& Hutrianto. (2017). System Usability Scale Antarmuka Palembang Guide Sebagai Media Pendukung Asian Games XVIII. Journal of Information System Engineering and Business Intelligence, 3(2).

[6] Pudjoatmodjo, B., \& Wijaya, R. (2016). Tes Kegunaan (Usability Testing) Pada Aplikasi Kepegawaian Dengan Menggunakan System Usability Scale. Seminar Nasional Teknologi Informasi Dan Multimedia 2016, 37-42.

[7] Aprilia H.N, I., Santoso, P. I., \& Ferdiana, R. (2015). Pengujian Usability Website Menggunakan System Usability Scale Website Usability Testing using System Usability Scale, 17(1), 31-38.

[8] Yuliyana, T., Arthana, R., \& Agustini, K. (2017). Usability Testing pada Aplikasi POTWIS.

[9] usability.gov. (2013c, October 8). Usability Evaluation Basics. Retrieved March 29, 2018, from 
(https://www.usability.gov/what-and-why/usability-evaluation.html)

[10 ] Battleson, B., Booth, A., \& Weintrop, J. (2001). Usability testing of an academic library Web site: A case study. Journal of Academic Librarianship, 27(3), 188-198. (https://doi.org/10.1016/S0099-1333(01)00180-X) 